\title{
Do variations in Arabian plate lithospheric structure control deformation in the Arabian-Eurasian convergence zone?
}

\author{
Robert J Stern ${ }^{1,3}$ and Peter R Johnson ${ }^{2}$ \\ ${ }^{1}$ Dept. of Geosciences, University of Texas at Dallas, Richardson TX 75080-3021, \\ USA \\ ${ }^{2}$ Johnson and Vranas Associates, 1242 Tenth Street, NW, Washington, DC 20001- \\ 4214, USA \\ E-mail: rjstern@utdallas.edu
}

\begin{abstract}
The Arabian plate has been converging with Eurasia for 20-30 Ma, currently at 2-3 $\mathrm{cm} /$ year. Convergence is manifested differently along strike, with collision and tectonic escape in the west (Anatolia) and subduction of Arabia beneath Eurasia in the east (Iran). The reason for these differences may reflect the greater density of the Arabian lithosphere in the east relative to that in the west. Five observations indicate that the eastern Arabian plate is more dense and thus easier to subduct than the western Arabia Plate: (1) the $>1000$ km-long, N-S trending Central Arabian Magnetic Anomaly (CAMA) marks a $\sim 600 \mathrm{Ma}$-old suture between E and W Arabia that (2) separates crustal tracts with distinct Neoproterozoic histories (850-750 Ma crust in the east, 850-570 Ma in the west); (3) E. Arabian (platform) crust is slightly thicker and more felsic than that of W. Arabia (shield) and thus more buoyant; (4) E. Arabia is underlain by thicker mantle lithosphere than W. Arabia; and (5) W. Arabia has a long history of uplift whereas E. Arabia has subsided throughout Phanerozoic time. We infer that regional variations in lithospheric thickness largely reflect the earlier stabilization (and onset of conductive cooling) of E. Arabia relative to W. Arabia, leading to the development of significantly thicker mantle lithosphere in the east relative to the west. This also explains why Arabia east of CAMA was inundated by shallow seas $\sim 540 \mathrm{Ma}$ ago and accumulated salt whereas Arabia west of CAMA did not, as well as the long history of subsidence of the Arabian Platform and uplift of the Arabian Shield. These differences in lithospheric thickness may have been further modified by thermal erosion in Cenozoic time due to Red Sea rifting and the Afar hotspot.
\end{abstract}

\section{Introduction}

The Arabian Plate is mostly continental crust and upper mantle, flanked on three sides by narrow strips of oceanic lithosphere. The Arabian Plate converges with Eurasia to the north at 2-3 cm/year [1]. There has been roughly $300-500 \mathrm{~km}$ of convergence since Arabia first arrived at the trench $20-30 \mathrm{Ma}$ ago [2], but plate convergence is partitioned differently along strike. Subduction north of the Persian Gulf forms the Zagros fold-and-thrust belt and Urumieh-Dokhtar magmatic arc, whereas continentcontinent collision in the west produced the Bitlis suture, delamination and related igneous activity in eastern Anatolia, and forces the Anatolian plate to escape westward along strike-slip faults (figure 1)[3]. The reasons for this striking difference between eastern and western parts of the convergence

3 To whom any correspondence should be addressed. 
zone may result from differences between the lithospheres of E and W Arabia.

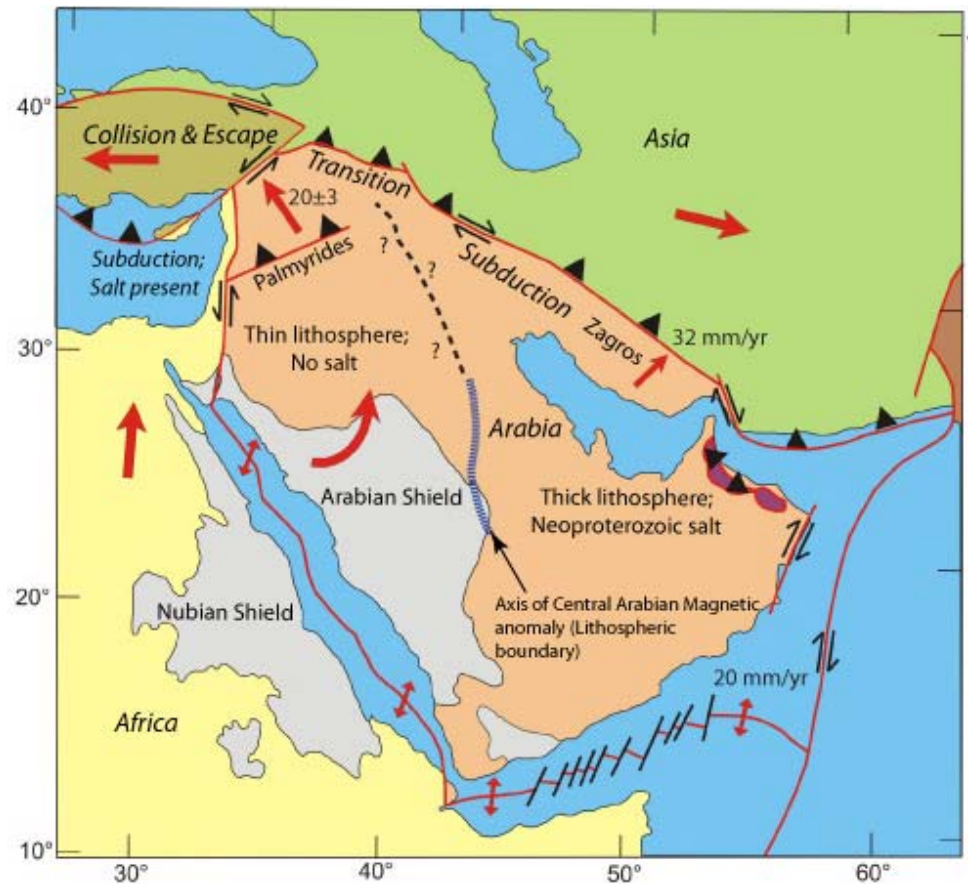

Figure 1. Simplified map of the Arabian and surrounding plates, with plate boundaries (red) and convergence vectors (red arrows). Grey areas are exposed basement. The Central Arabian Magnetic Anomaly marks a fundamental boundary between lithospheres of eastern and western Arabia; northward extension of CAMA (dashed with question marks) is speculative.

\section{Formation of Arabian Plate Continental Lithosphere}

Upper continental crust exposures dominate western Arabia (Arabian Shield) and occur as scattered small outcrops in eastern Arabia. Basement rocks mostly yield Neoproterozoic radiometric ages (but with significant tracts of Paleoproterozoic and Archean crust in the southern Shield and Yemen). Geochronologic and isotopic data indicate that most Arabian plate crust formed during about $300 \mathrm{Ma}$ of Neoproterozoic time, 870 to $570 \mathrm{Ma}$ ago. Arabian Shield crust makes up about half of the ArabianNubian Shield (ANS). The Arabian-Nubian Shield comprises one of the great tracts of juvenile continental crust on Earth and the northern half of the East Africa-Antarctic Orogen (EAAO) [4], which formed when large fragments of Eastern and Western Gondwana and intervening oceanic arcs collided $\sim 620-570 \mathrm{Ma}$ ago. Collisional tectonics to form crust of the Arabian Shield was succeeded by extension/collapse resulting in inundation, as manifested by deposition of carbonate sediments like those of the $\sim 590$ Ma Muraykhah Formation [5] and Dhaiqa Formation [6]. The nature of buried crust east and north of the Arabian Shield is less clear. The Central Arabian Magnetic Anomaly (CAMA) trends N-S for $800 \mathrm{~km}$ and can be traced due north across the Saudi Arabia-Iraq border, perhaps as far as the Zagros Orogenic Belt [7]. CAMA can be traced onto the easternmost Shield as the Al Amar fault, also known as the Amar suture [8]. This suture separates igneous rocks of the $>689-625 \mathrm{Ma} \mathrm{Ar}$ Rayn magmatic arc [9] to the east from granites and thick sediments (Abt formation) of the Ad Dawadimi terrane to the west. CAMA thus marks a fundamental tectonic boundary that formed $\sim 600$ Ma ago [10], between juvenile Neoproterozoic (ANS-like) crust to the west and poorly known crust to the east. Crust to the east of CAMA is poorly known. Scattered basement exposures east of CAMA are Neoproterozoic, with no evidence for pre-Neoproterozoic ages or isotopic compositions. Our present understanding of E. Arabia crust is that igneous activity ended and the crust began to stabilize $\sim 750 \mathrm{Ma}$ ago, almost $200 \mathrm{Myr}$ before stabilization of W. Arabia, as recorded in rocks of the Arabian Shield $[11,12,13,14,15,16]$.

One of the most important late Neoproterozoic events affecting the western part of the Arabian Shield was development of NW-SE trending Najd faults and shear zones during collision between Eastern and Western Gondwana. Displacements as large as $400 \mathrm{~km}$ are inferred across some of these faults [17], which occurred $\sim 580-640 \mathrm{Ma}$ ago. These shears are thought to have resulted as far-field 
effects due to continent-continent collision to form the southern EAAO [18]. These shears are steep at the surface but likely flatten at depth, reflecting the fact that Arabian crust was still quite hot at this time, and mid-crustal levels were almost certainly weak. Such listric faults, especially where these interacted with the abundant intrusions, were surely instrumental in shaping the structure of the crust that we observe today. It is not clear whether this shear system affected eastern Arabia; a magnetic map of central Arabia shows the N-S trending CAMA as continuous from $21^{\circ}$ to $29^{\circ} \mathrm{N}$, with no indication of significant sinistral offsets [8].

\section{Phanerozoic Sedimentation and Subsidence}

Clues to lithospheric structure may be found in the thick sedimentary cover of the Arabian Platform, which contrasts with uplifted crust of western Arabia. One possibility to explain the Shield/Platform dichotomy is that the Shield was dynamically uplifted recently due to hot mantle of the Afar plume and because of Red Sea rifting, whereas the Platform was not. Another possibility is that much older crust and lithosphere underlies the Arabian Platform whereas more buoyant crust and lithosphere of Neoproterozoic age underlies the Arabian Shield. A third possibility is that crust beneath the Shield and Platform are of similar age but are associated with a lithosphere is significantly thicker beneath the Platform. These different explanations imply different timings for the structural differentiation of Arabian plate crust into shield and platform. Choosing the best explanation requires understanding the depositional history of Arabian Plate sediments, which preserve the history of regional uplift and subsidence.

Regions of Arabia now defined as Platform and Shield behaved similarly until about $\sim 750 \mathrm{Ma}$ ago, with tectonics and sedimentation dominated by active magmatic activity across a broad region; these blocks coalesced by $\sim 560 \mathrm{Ma}$. But after $\sim 750 \mathrm{Ma}$ ago, eastern Arabia stabilized as a neocraton, overlain by a shallow marine environment, and has since subsided more or less continuously to accommodate up to $12 \mathrm{~km}$ of sediment. The start of this subsidence is best seen in the Huqf Supergroup and end-Neoproterozoic salt basins $[19,20]$. In contrast, shield regions were variably above sea level after $\sim 750 \mathrm{Ma}$ ago, and repeatedly uplifted and depressed, developing unconformities and continental sedimentary basins.

The eastern Arabian platform maintained marine to shoreline conditions for most of Phanerozoic time. Steady subsidence was periodically interrupted by block faulting and erosion (e.g., the uplift of the Central Arabian Arch and removal of Lower Paleozoic sediments [21], but subsidence always resumed. In contrast, the shield was possibly covered by fluviatile-shallow marine deposits during the Lower Paleozoic, but thereafter was largely emergent. From these observations, we infer that the differentiation of Arabian plate continental crust into uplifted shield and subsided platform began at $\sim 750 \mathrm{Ma}$ ago.

\section{Geophysical Insights into the causes of Arabian Plate Uplift and Subsidence}

\subsection{Crustal Thickness \& Velocity Structure}

At issue here is the need to establish the typical thickness of Arabian plate continental crust and whether there are any significant regional differences in structure and thickness of crust and lithosphere. Thickness estimates are made from crustal refraction, teleseismic receiver function, and surface wave studies. A major crustal refraction experiment was undertaken in 1978, a SW-NE oriented, 1000-km long profile from near Riyadh on the Arabian platform to the Red Sea [22, 23, 24, 25]. This showed the crust to range from $43 \mathrm{~km}$ thick near Riyadh to $38 \mathrm{~km}$ near the Red Sea (figure 2 ), with a significant change in inferred upper crustal structure on either side of CAMA. The crust is composed of two layers, each about $20 \mathrm{~km}$ thick, with average P-wave velocities of about 6.3 and 7.0 $\mathrm{km} / \mathrm{sec}$, respectively $[22,23]$. This velocity structure indicates that intermediate to felsic upper crust overlies mafic lower crust across a well-defined Conrad Discontinuity. Support for the interpretation of mafic lower crust beneath the Arabian Shield comes from mafic lower crustal xenoliths brought up in Neogene lavas $[26,27,28]$. Teleseismic receiver functions recorded at 23 stations in Saudi Arabia 
and Jordan analyzed by [29] indicate that the average crustal thickness beneath the Arabian shield is $39 \mathrm{~km}$, consistent with results from refraction studies. A surface wave study of the entire shield indicated that the Moho lies 41-46 km deep [30].

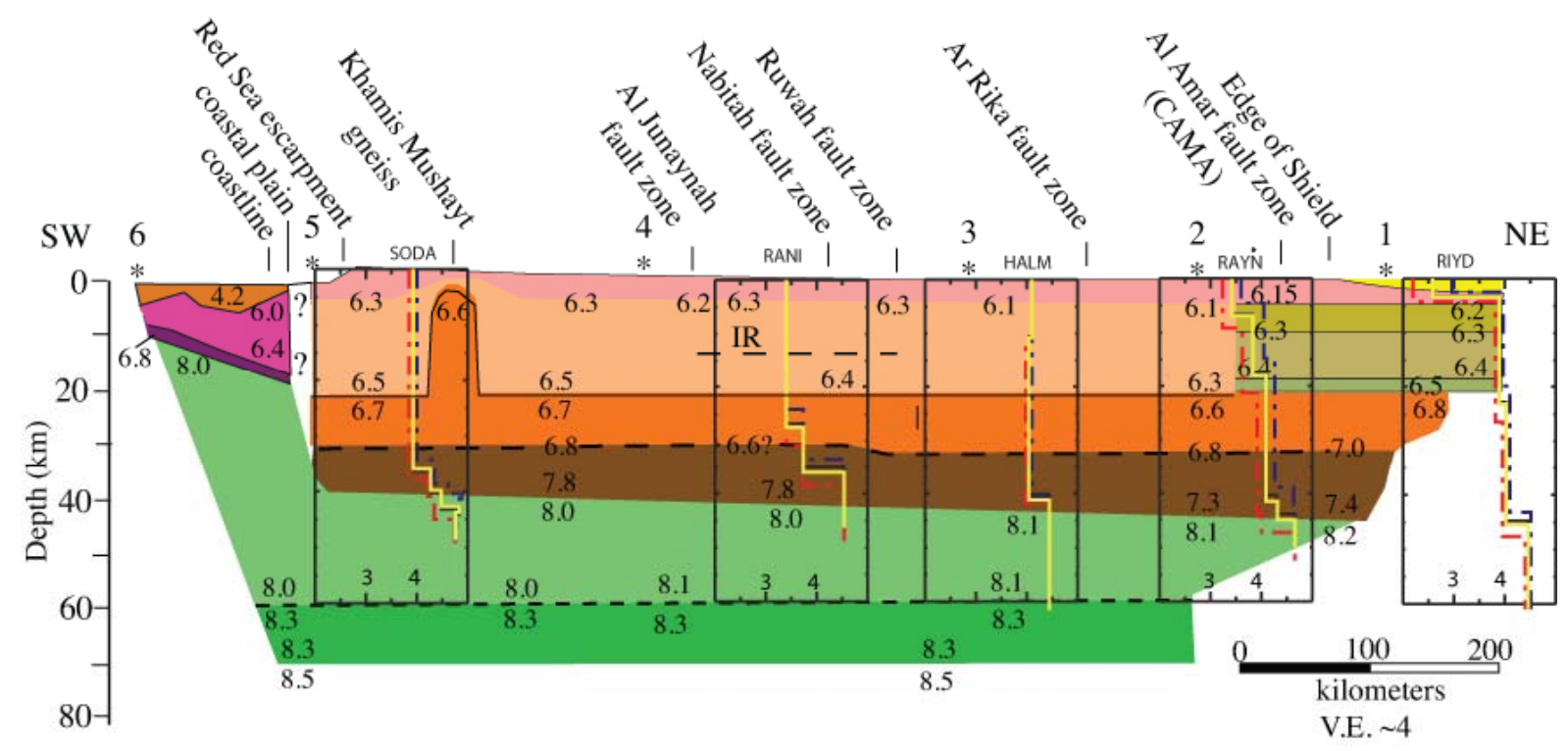

Figure 2. Interpretive crustal section for the 1978 seismic refraction profile across the Shield in southern Saudi Arabia, from the Red Sea to slightly east of the Arabian Shield [22]. P-wave velocities for each layer are given in $\mathrm{km} / \mathrm{sec}$. Numbers above asterisks $=$ shot points. Overlain on this is shearwave velocity structure from receiver function stacks of [31] for seismic stations at SODA, RANI, HALM, RAYN and RIYD. The yellow line is the optimal receiver function S-wave mode assuming a Poisson's ratio of 0.25 ; red and blues lines show 2 SD error ranges. Note similarities and differences between Moho determined by refraction to occur just above where $\mathrm{Vp} \sim 8 \mathrm{~km} / \mathrm{sec}$ (boundary between brown to green) and receiver function inference drawn where $\mathrm{Vs} \sim 4.6 \mathrm{~km} / \mathrm{sec}$ (short dashed line).

Crust beneath the northern Arabian plate is thinner, from 33 to $37 \mathrm{~km}$, although a thickness of $\sim 40 \mathrm{~km}$ was determined in the extreme north, just south of the Bitlis suture, according to receiver function studies [32]. Gravity models indicate that the crust beneath Syria is $\sim 32 \mathrm{~km}$ thick [33]. combined gravity modeling and receiver function analysis to show that the crust of Syria north of the Palmyrides (figure 1) is significantly thinner $(\sim 25 \mathrm{~km})$ than that to the south $(\sim 35 \mathrm{~km})$ [34]. Combined P-wave receiver functions and surface (Rayleigh) waves have been used to image the crust beneath two sites in Iraq: Mosul (near the Zagros Fold Belt) and Baghdad (in the Mesopotamian Foredeep). These results show that the crust is $39 \mathrm{~km}$ thick beneath Mosul and $43 \mathrm{~km}$ thick beneath Baghdad, and that crustal structure beneath these regions is similar [35]. These indications of variable (and often thinner) crustal thicknesses in the north may reflect the effects of Permo-Triassic and Mesozoic rifting associated with the formation of Tethys.

There are few geophysical studies of crustal and lithospheric structure beneath the Arabian Platform, but some evidence indicates different crustal compositions on either side of CAMA. [36] first showed evidence that the crust of the Arabian Platform was geophysically distinct from that of the Arabian Shield, using surface waves and teleseismic body wave arrivals. They found that the crust beneath the platform was slightly thicker $(40 \mathrm{~km})$ and slower $(\mathrm{Vp}=6.1 \mathrm{~km} / \mathrm{sec})$ than that beneath the shield and did not have a strong velocity gradient, consistent with an overall felsic crust for E. Arabia. In contrast, crust beneath the Arabian Shield is thinner $(36 \mathrm{~km}), \sim 6 \%$ faster, and shows a significant increase in velocity with depth, indicating mafic lower crust. It thus appears that the crust east of CAMA is slightly thicker and more felsic than that to the west, although more geophysical 
investigations are needed to test this idea. If confirmed, these results indicate that the crust east of CAMA should be elevated relative to the crust to the west, due to isostasy; this is opposite to what is observed, with the Shield elevated to the Platform.
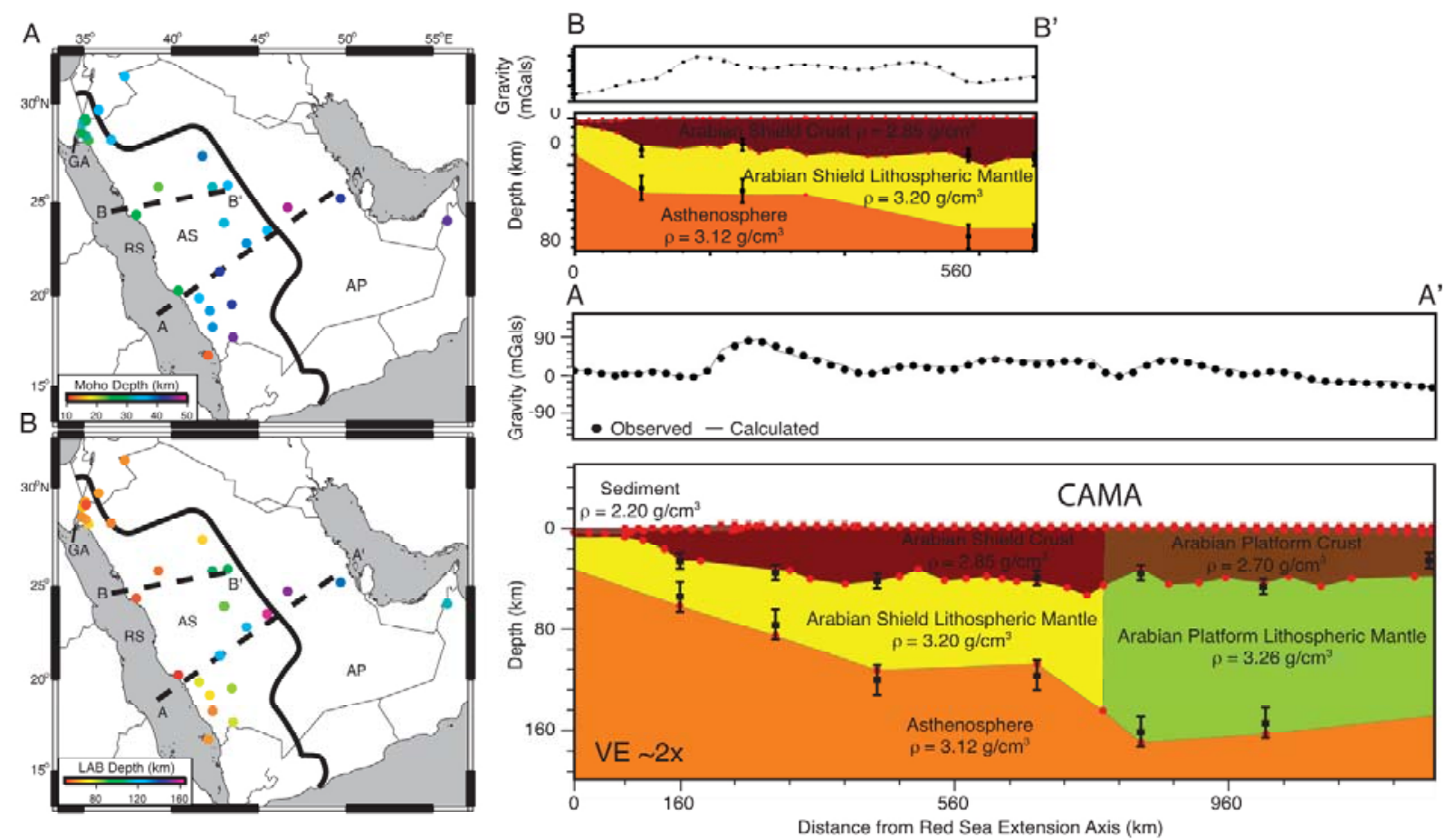

Figure 3. Thickness of crust and lithospheric mantle beneath western Arabia, modified after [37]. Colored circles on maps show the A) depth to Moho and B) depth to the lithosphere-asthenosphere boundary (LAB). The solid line approximates the boundary between the Arabian Shield (AS) and the Arabian Platform (AP) while the two dashed lines mark the locations of cross-sectional profiles AA' $^{\prime}$ and BB'. RS: Red Sea, GA: Gulf of Aqaba. Profiles on right show gravity signature and lithospheric structure along cross-sectional profile $\mathrm{BB}^{\prime}$ and $\mathrm{AA}^{\prime}$. Comparisons are shown between observed gravity from the GRACE satellites (black dots) and the calculated gravity (grey line) resulting from the lithospheric models shown below them. Red dots mark nodes that were used in the gravity modeling to constrain the boundary depths, and the densities $(\rho)$ of each layer are listed. For stations along the profile, the Moho and LAB depths from receiver function analysis are shown by black squares with error bars. Errors on Moho and LAB depths are 5 and $10 \mathrm{~km}$, respectively, and agree within error with the gravity model. Note that the jump in lithospheric thickness shown on profile AA' occurs beneath CAMA.

\subsection{Lithospheric Thickness}

The thickness of Arabian plate lithosphere, or the depth to the lithosphere-asthenosphere boundary (LAB) is difficult to determine because velocity contrasts across this boundary are small. Hansen et al. [37] used S-wave receiver functions and supplemented these by modeling GRACE gravity to estimate the depth to the LAB (figure 3). They found that the LAB along profile AA' near the Red Sea coast lay $\sim 50 \mathrm{~km}$ deep but increases to about $120 \mathrm{~km}$ beneath the Arabian Shield. A significant increase in lithospheric thickness is observed beneath the Shield-Platform boundary, where [37] show the LAB depth increasing to about $160 \mathrm{~km}$. The results of Hansen et al (2007) showing thicker mantle lithosphere east of CAMA highlights its significance as marking an important lithospheric boundary.

\section{Implications for the Evolution of the Arabian Continental Lithosphere and the Arabia- Eurasia Convergence Zone}


Combined geologic and geophysical insights outlined above suggest five important points: (1) an important Neoproterozoic geosuture (CAMA) can be traced magnetically from central Arabia northwards; (2) that this separates crustal tracts with distinct Neoproterozoic histories (older in the east, younger in the west); (3) that E. Arabian (Platform) crust is slightly thicker and more felsic than that of W. Arabia (Shield) and thus more buoyant; (4) that E. Arabia is underlain by thicker lithosphere than that of W. Arabia; and (5) that W. Arabia has a long history of uplift whereas the platform has long subsided. Future studies are needed to confirm observations (2), (3), and (4), but if correct, these observations compel three conclusions. First, crustal variations cannot explain uplift of E. Arabia and subsidence of W. Arabia, because thicker, less dense E. Arabia crust should stand higher than thicker, denser W. Arabia crust due to isostasy. Second, regional variations in lithospheric thickness can explain uplifted Shield and subsided Platform as due to isostasy, because lithosphere $(\sim 3.3 \mathrm{~g} / \mathrm{cc})$ is denser than asthenosphere $(\sim 3.25 \mathrm{~g} / \mathrm{cc})$, pulling down E. Arabia relative to W. Arabia. Third, regional variations in lithospheric thickness largely reflect the earlier stabilization of E. Arabia relative to W. Arabia. Continental Arabian plate mantle lithosphere began to form when igneous activity ceased, thickening with time due to conductive cooling, which began 150-200 Myr earlier in the east than in the west. This explains why Arabia east of CAMA was inundated by shallow seas $\sim 540 \mathrm{Ma}$ ago and accumulated salt whereas Arabia west of CAMA did not, as well as the long history of subsidence of the Arabian Platform and uplift of the Arabian Shield. These differences in lithospheric thickness may have been further modified by thermal erosion in Cenozoic time due to Red Sea rifting and the Afar hotspot.

We infer that E-W variations in Arabian Plate lithospheric thickness affected the Arabia-Eurasian convergence zone. Using the crustal and lithospheric thicknesses and densities of figure 3 (A-A'), Arabia west of CAMA has a density of $3.08 \mathrm{~g} / \mathrm{cc}$ whereas to the east the density is $3.12 \mathrm{~g} / \mathrm{cc}$, making E. Arabia significantly easier to subduct than W. Arabia. In addition, the presence of Neoproterozoic salt in the east conceivably reduced friction on the plate interface, allowing Platform sediments to be scraped off to form the Zagros fold-and-thrust belt. In contrast, the thinner lithosphere of W. Arabia resulted in significantly lower densities in spite of the presence of denser crust in the west than in the east. The relatively buoyant lithosphere of W. Arabia is not easily subducted, leading to collision in the western part of the convergence zone.

\section{References}

[1] Bird P 2003 Geochem. Geophys. Geosys. 41027 doi:10.1029/2001GC000252

[2] Allen M, Jackson J and Walker R 2004 Tectonics 23 TC2008 doi:10.1029/2003TC001530

[3] Vita-Finzi C 2001 J Struct. Geol. 23 521-30

[4] Jacobs J and Thomas R J 2004 Geology 32 721-24

[5] Nicholson P G, Janjou D, Fanning C M, Heaman L M and Grotzinger J P 2008 GEO 2008: Middle East Geoscience Conference and Exhibition (Manama, Bahrain, 3-5 March 2008)

[6] Miller N, Johnson P R and Stern R J 2008 Arab J. Sci. Eng. 33 55-77

[7] Johnson P R and Stewart I C F 1995 Tectonophysics 245 37-52

[8] Al-Husseini M 2000 GeoArabia 5 527-42

[9] Doebrich J L, Al-Jehani A M, Siddiqui A A, Hayes T S, Wooden J L and Johnson P R 2007 Precamb. Res. 158 17-50

[10] Johnson P R and Kattan F H 2008 Arab J. Sci. Eng. 33 3-16

[11] Gass I G, Ries A C, Shackleton R M and Smewing J D 1990 Tectonics, geochronology and geochemistry of the Precambrian rocks of Oman (Geology and Tectonics of the Oman Region) eds A H F Robertson, M P Searle and A C Ries (London: Geological Society of London, Special Publication) 49 585-99

[12] Mercolli I, Briner A P, Frei R, Schönberg R, Nägler T F, Kramers J and Peters T 2006 Precamb. Res. 145 182-206

[13] Allen P A and J Leather 2006 Precamb. Res. 144 167-198

[14] Pallister J S, Cole J C, Stoeser D B and Quick J E 1990 Geology 18 35-39 
[15] Roger J et al 1991 Geologic Map of J'alan, sheet NF 40-8E, Scale 1:100,000, with Explanatory notes Directorate General of Minerals, Oman Ministry of Petroleum and Minerals

[16] Würsten F et al 1991 The Uplift History of the Precambrian Crystalline Basement of the jabal J'alan (Sur, Area) (Ophiolite Genesis and Evolution of the Oceanic Lithosphere) eds T Peters, A Nicolas and R G Coleman (Dordrecht) 613-26

[17] Davies F B 1984 J. Geology 82 37-53

[18] Stern R J 1994 Annual Rev. Earth Planet. Sci. 22 319-51

[19] Husseini M I and Husseini S I 1990 Origin of the Infracambrian Salt Basins of the Middle East (Classic Petroleum Provinces) ed J Brooks (London: Geological Society of London Special Publication)

[20] Allen P A 2007 Earth Science Rev. 84 139-85

[21] Alsharan A S and Nairn A E M 1997 Sedimentary Basins and Petroleum Geology of the Middle East (Amsterdam: Elsevier) 942 pp.

[22] Mooney W D, Gettings M E, Blank H R and Healy J H 1985 Tectonophysics 111 173-246

[23] Gettings M E, Blank H R, Mooney W D and Healey J H 1986 J. Geophys. Res. 91 6491-512

[24] Badri M 1991 Tectonophysics 185 357-74

[25] Mechie J, Prodehl C and Koptschalitsch G 1986 Tectonophysics 131 333-52

[26] McGuire A V and Stern R J 1993 Contrib. Mineral. Petrol. 114 395-408

[27] Nasir S 1995 Eur. J. Mineral. 7 217-30

[28] Al-Mishwat A T and Nasir S J 2004 Lithos 72 45-72

[29] Al-Damegh K, Sandoval E and Brazangi M 2005 Earth Planet. Sci. Lett. 231 177-96

[30] Mokhtar T, Ammon C J, Herrmann R B and Ghalib H A A 2001 Pure Appl. Geophys. 158 $1425-44$

[31] Sandvol E, Seber D, Barazangi M, Vernon F, Mellors R and Al-Amri A 1998 Geophys. Res. Lett. $252873-76$

[32] Angus D A, Wilson D C, Sandvol E and Ni J F 2006 Geophys. J. Int. 166 1335-46

[33] Al-Saad D, Sawaf T, Gebran A, Barazangi M, Best J A and Chaimov T A 1992 Tectonophysics $207345-358$

[34] Brew G, Barazangi M, Al-Maleh A K and Sawaf T 2001 GeoArabia 6 573-616

[35] Gök R, Mahdi H, Al-Shukri H and Rodgers A J 2008 Geophys. J. Int. 172 1179-87

[36] Rodgers A J Walter W R, Mellors R J, Al-Amri A M S and Zhang Y-S 1999 Geophys. J. Int. 138 871-78

[37] Hansen S E, Rodgers A J, Schwartz S Y and Al-Amri A M S 2007 Earth Planet. Sci. Lett. 259 256-65 